\title{
Epilogue: Learning, Unlearning, and Relearning
}

\section{Karijn van den Berg, Constance Dupuis, Jacqueline Gaybor, and Wendy Harcourt}

The process of engaging with and learning from each other that culminated in this book has been a beautiful experiment in community building. We are grateful for the time and care that each contributor has put into this-beginning with shared laughter and good food in an idyllic

K. van den Berg $(\bowtie)$

University of Amsterdam, Amsterdam, The Netherlands

e-mail: k.vandenberg@uva.nl

C. Dupuis - W. Harcourt

International Institute of Social Studies, Erasmus University Rotterdam, The Hague, The Netherlands

e-mail: dupuis@iss.nl

W. Harcourt

e-mail: harcourt@iss.nl

J. Gaybor

Rutgers Kenniscentrum Seksualiteit, Utrecht, The Netherlands e-mail: j.gaybor@rutgers.nl

W. Harcourt et al. (eds.), Feminist Methodologies,

Gender, Development and Social Change, https://doi.org/10.1007/978-3-030-82654-3_14 
setting in Bolsena, Italy, and continuing with the unhurried reading of and commenting on each other's draft chapters. By way of bringing the collection to a close, we, the editors, offer a few reflections on how to do feminist research. We open up questions around: what it means to trouble and be troubled by; how to learn and unlearn together; and in what ways our methodologies take us beyond academic knowledge production.

As we wrote at the beginning of this book, as feminists we are making explicit the importance of "troubling" and "being troubled by" feminist research and feminist methodologies. The different reflections offered throughout the book reveal how "doing" feminist methodologies is in itself an act of troubling and being troubled by. The status quo of Western, rational knowledges is being challenged, as feminists raise questions that may throw us off balance. The book intentionally asks:

- Whose work are we reading and citing? With whose thoughts are we thinking through our research questions?

- Which stories do we centralize and how do we tell those stories?

- How do we reflexively work through our privileges and multi-fold positionalities and how they affect our research and relationships?

Such questions are not only part and parcel of engaging with feminist methodologies and doing research as feminists, they are also critical to understanding what we can and what we cannot "produce" as knowledge.

Being "troubled" by questions around our responsibilities, feminist ethics and our research practices means that we need both to learn and unlearn. Unlearning entails an undoing of the normative frameworks and paradigms in which we find ourselves. It also means we can end up with more questions than answers. A practice of unlearning, of not knowing, requires the sort of openness that is central to a feminist ethics and practice of care. So, while many of the chapters seek to learn and to share experiences of self-learning, this collection may leave the reader with new openings and questions rather than necessarily new empirical knowledge. The different authors are honest in the challenges of doing feminist research. These are challenges that will continue, reflective of feminist methodologies as being confrontational and uncomfortable.

The threads of learning to unlearn that run throughout the book are not only challenging but also inspiring as they give space and importance to the "in between" parts of research, the quiet moments of insight and 
connection. As was briefly touched upon in the introduction, feminist ethics asks us to make visible the sometimes messy but necessary aspects of the research process. There is always something troubling about being explicit about the "in between" of research-is research what is actually needed? We think here of Eve Tuck and Wayne Yang's work on refusal in research. ${ }^{1}$ As the book shows, feminist approaches take time, require flexibility, and demand that we put more of our whole selves into our work. We bring feminist methodologies to our work because we care. There is a continual tension around why we do academic research, paying attention to what impact our research can make beyond the academic realm. We continue to be challenged to ensure that academic outputs are not the main focus of our research relations.

By paying attention to research relations, the authors have also embraced an examination of the connections among emotional, bodily and thought processes which make up feminist knowledge production. This focus has unveiled the diversity in gendered lived experiences, inequalities and injustices. Such explorations are an invitation to question how we move across the porous boundaries of our individual lives and experiences and our research projects and connect to others, including the more than human. The chapters look at the quality of our research relationships with humans and more-than-humans and how our engaging in feminist research requires awareness and sensitivity to what change we are bringing. Our passage through certain places leaves traces, sometimes invisible to our senses, but very persistent for others. How do we gain the sensitivity to navigate these waters with care? Who and what is this research for? We acknowledge that these questions are not easy to resolve. Rather, they are opportunities to be open and engage in productive discussions and listen to each other.

Even as the book opens up more questions, inviting readers to learn, unlearn and relearn through our research, navigating dominant structures of knowledge production as troubled and troubling feminists, we also invite celebration. This book has been a creative, evolving process of doing feminist research that has been explicitly experimental as we have learnt together. The process of putting together the book has been such a vital, exciting collaboration. We questioned ourselves as researchers,

\footnotetext{
${ }^{1}$ Tuck, E., \& K.W. Yang. (2014). R-Words: Refusing Research. In D. Paris \& M.T. Winn (eds.) Humanizing Research: Decolonializing Qualitative Inquiry with Youth and Communities, pp. 223-47. Los Angeles: Sage.
} 
asking each of us to be explicit about our engagement as feminists, and of our relations with others as we wrote our contributions. We asked what being a feminist meant in relation to: the questions that inspired us; who and what accompanied us in our research; and what we meant to each other as co-authors and editors. We troubled each other in gentle ways, probing carefully as we gave each other permission to speak about the difficulties of doing feminist research. We asked ourselves to be open not only to the challenges but also to the pain. We wrote of what we wanted to do as well as what could not be done. As we reflected together (mostly online) we would often remark how much we enjoyed reading and learning from each other as we found the courage to acknowledge and write about the emotions, fears, and possibilities of doing feminist research. It was a positive, reaffirming, if troubling, experience.

We thank the reader for joining us in our journey.

Open Access This chapter is distributed under the terms of the Creative Commons Attribution 4.0 International License (http://creativecommons.org/ licenses/by/4.0/), which permits use, duplication, adaptation, distribution and reproduction in any medium or format, as long as you give appropriate credit to the original author(s) and the source, a link is provided to the Creative Commons license and any changes made are indicated.

The images or other third party material in this chapter are included in the work's Creative Commons license, unless indicated otherwise in the credit line; if such material is not included in the work's Creative Commons license and the respective action is not permitted by statutory regulation, users will need to obtain permission from the license holder to duplicate, adapt or reproduce the material.

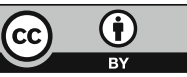

